\title{
Seasonal Incidence of Insect Pest Species of Paddy Collected through Light Trap
}

\author{
Yogendra Kumar Mishra*, A.K. Sharma, A.K. Bhowmick, A.K. Saxena and Anil Kurmi
}

Department of Entomology, College of Agriculture, Jabalpur, Jawaharlal Nehru

KrishiVishwaVidyalaya, Jabalpur-482004, Madhya Pradesh, India

*Corresponding author

\section{Keywords}

Light Trap,

Seasonal Incidence,

Rice, Insect Pest

Species

Article Info

Accepted:

04 March 2019

Available Online:

10 April 2019

\section{A B S T R A C T}

The present investigation study on Seasonal Incidence of Insect Pest Species of Paddy Collected Through Light Trapat Jabalpur was carried out at the Krishi Nagar experimental farm, Adhartal, JNKVV, Jabalpur, Madhya Pradesh during the period between the last week of June to the last week of December, 2015.Result showed that all 8 species were identified as pests of paddy having regular occurrence in light trap catches i.e. Rice gundhi bug, Leptocorisa acuta (Thunberg), Green leaf hopper, Nephotettix virescens (Distant), Army worm, Mythimna separata (Walker), Rice leaf folder, Cnaphalocrocis medinalis (Guene), Rice butterfly, Melanitis ledaismene Cramer, Short horn grass hopper, Tetrix subulata Linnaeus, Field cricket, Euscyrtus concinnus (de Haan) and Mole cricket, Gryllotal paorientalis Burmeister. Correlation studies revealed that between various weather parameters and Rice gundhi bug, Leptocorisa acuta (Thunberg), Green leaf hopper, Nephotettix virescens (Distant), Army worm, Mythimna separata (Walker), Rice leaf folder, Cnaphalocrocis medinalis (Guene)catches were found non significant and Rice butterfly, Melanitis ledaismene Cramer and Short horn grass hopper, Tetrix subulata Linnaeus showed that significant positive correlation with maximum temperature while Field cricket, Euscyrtus concinnus (de Haan), Mole cricket, Gryllotalpa orientalis Burmeister catches were found significant positive correlation with maximum temperature and evaporation.

\section{Introduction}

Light trap is an important tool for minimizing the insect pests damage without any toxic hazards (Sharma et al., 2004). Other than this light trap has been used to supplement the knowledge of pest fauna of given locality, geographical distribution and their seasonal activity etc. (Verma andVaishampayan, 1983 and Sharma et. al., 2010). Light trap is also useful to know the effect the weather factors on species abundance (Jonason et al., 2014).

Many insects are positively phototrophic in nature and use of light traps for insect catches produces valuable faunistic data. This data can be seen as a parameter of health of biodiversity of the concerned vicinity. The data provided by light trap catches could throw light on period of maximum activity of 
insects (Dadmal and Khadakkar, 2014). Ramamurthy et al., (2010) used Mercury, Black and Ultra-violet light traps for insect capture and found that Coleopterans dominate the catches followed by Hemipterans, Hymenopterans and Lepidopterans. Light trap plays an important role in monitoring and management of insect pest population in Agro-ecosystem. The phototropic behavior of insects makes the scientist capable to use light trap for capturing insects either for study or destruction.

Rice (Oryza sativa L.) is an important cereal crop in the world serving as staple diet for millions of peoples. Rice stand second in the world after wheat in area and production. Almost $90 \%$ of rice is grown and consumed in Asia (Anonymous, 2015).

In India it is cultivated in an area of 44.00 million hectares with a production of 104.80 million tonnes and productivity of $2177 \mathrm{~kg}$ ha ${ }^{1}$ whereas estimated production in 2015-16 is 106.10 million tonnes. In Madhya Pradesh the area, production and productivity of rice are 1.76 million hectares, 1.87 million tones and $1062 \mathrm{~kg} \mathrm{ha}^{-1}$ respectively, which is far below the national average (Anonymous, 2016).

Worldwide food plants are damaged by more than 10,000 species of insects. In India average losses in paddy production due to insect pests are 25-30\% (Dhaliwal and Arora, 2010) and in Madhya Pradesh about 40-100 $\%$ losses were observed (Dhamdhere, 1990). Pathak and Dhaliwal (1981) reported that over 100 insect pest species attacks paddy crop at various stages of its growth in which 20 species cause the economic damage.

The forecasting and predication of insect occurrence or outbreak can be made by using light trap. These studies are helpful in the rational and timely application of insecticide which may lead to better and cheaper insect control with least hazards.
Shimoda and Honda (2013) observed that nocturnal insects are often attracted to light sources that emit large amount of UV radiation, and devices that exploit this behavior, such as light traps for forecasting pest outbreaks and electric insect killers, have been developed. Light trap are also found effective in minimizing the insect pests population in different crops, Sharma and Vaishampayan (2009) evaluated light trap as direct control tool against major pest species of paddy in Jabalpur M.P., with exception of army worm Mythimna separata (Walker). Results have consistently proved the utility of light trap as direct control tool against remaining three major species namely Sogatella furcifera (Horvath), Cnaphalocrocis medinalis (Guene) and grass hopper (Complex). Effective coverage area was between 100-200 m distances from trap covering around 5 to 6 ha of crop area per trap.

Muchala (2014) revealed that 69 species belonging to 11 orders and 37 families were recorded throughout the season (kharif2013). Based on number of species collected, largest collection was represented by order Lepidoptera (20 species) and followed by orders Hemiptera (15 species), Coleoptera (15 species), Orthoptera (6 species) and Hymenoptera (5 species) in descending order respectively and natural bio-control agents was represented by 7 orders, 15 families and 25 species as predators and 1 order, 3 families and 4 species as parasites.

Extensive work has been carried out on various aspects of light-trap designs, light sources and use of light trap against pests of pulses, but very little information is available on insect pests of paddy in central India (Mahakaushal region of M.P.). Therefore, the present investigation is proposed to observe the "Seasonal Incidence of Insect Pest Species of Paddy Collected Through Light Trap". 


\section{Materials and Methods}

Present experiment entitled, "Seasonal Incidence of Insect Pest Species of Paddy Collected through Light Trap" was carried out at the Krishi Nagar experimental farm, Adhartal, JNKVV, Jabalpur, Madhya Pradesh during the period between last week of June and last week of December, 2015.

\section{Details of light trap unit}

New Jawahar light trap model developed at JNKVV, Jabalpur with mercury vapor lamp $(80 \mathrm{~W})$ as light source was used for the present study. The light trap units comprised of two components are as follows:-

\section{Trapping device}

It is made up of 24 gauge GI sheet consisting of a funnel ( $40 \mathrm{~cm}$ top diameter), baffle plates each $30 \times 12 \mathrm{~cm}$ in size. In this design long funnel stem (pipe) is provided in place of collection chamber which is directly attached to collection trey.

\section{Insect collection device}

It is made up of 24 gauge GI sheet $40 \mathrm{~cm}$ x 40 $\mathrm{cm} \times 15 \mathrm{~cm}$ in size with cupboard and built-in locking system. The insects collected in the chamber of light trap were killed by the exposure of Dichlorvos 76 EC vapours (as fumigating agent) which is directly placed in collection tray for instant killing of trapped insects.

\section{Observation procedure}

Seasonal activity study of major insect pest species of paddy was recorded by operating the light trap in Kharif season of 2015. Major and minor pests of paddy were observed on daily basis. In order to study the seasonal activity, daily trap catch was converted into weekly total and mean per day per week (weekly mean/day).

Weekly divisions are based on standard meteorological week. Observations of weather data (Maximum temperature, Minimum temperature, relative humidity morning and evening, rainfall, number of rainy days, sunshine hours, wind velocity, morning and evening vapour pressure and evaporation etc.) were recorded on daily basis from JNKVV meteorological observatory.

The correlation coefficient between major insect pests of paddy and various weather parameters was calculated by using the correlation regression analysis.

\section{Statistical method}

Correlation and regression of the abiotic factors on major insects were worked out by using the formula as suggested by Snedecor and Cochran (1967).

Correlation ${ }^{\mathrm{s}} \mathrm{r}=\frac{\sum x y-\frac{\sum x \cdot \Sigma y}{n}}{\sqrt{\left\{\sum_{x} 2-\frac{\left(\left(\sum x\right)^{\mathrm{n}}\right)}{n}\right\}\left\{\sum_{y} 2-\frac{\left(\left(\sum y\right)^{\mathrm{x}}\right)}{\mathrm{N}}\right\}}}$

Regression ${ }^{\widehat{Y}}=a+b x\left(R^{2}\right)$

$\mathrm{a} \quad=$ Intercept.

$\mathrm{b}=$ Regression coefficient.

$\mathrm{R}^{2}=$ Coefficient of multiple determination.

Test of significance ' $r$ '

$t=\frac{r}{\sqrt{1-r^{2}}} \sqrt{n-2}$

\section{Results and Discussion}

Seasonal incidence of major insect pest of paddy collected in light trap were studied by 
operating, Jawahar light trap (with 80 Watt mercury vapour lamp) in paddy field at Krishi Nagar experimental farm, Adhartal during kharif 2015 (June to December). The data of every day catch of major insect pest species of paddy collected in trap were converted to standard weekly averages. In all 8 species were identified as pests of paddy having regular occurrence in light trap catches (Table 1).

\section{Correlation studies}

The correlation coefficients among various insect population and weather parameters viz., maximum temperature, minimum temperature, sunshine (Table 2, 3 and 4), wind velocity, morning relative humidity, evening relative humidity, rainfall, morning vapor pressure, evening vapor pressure, evaporation and number of rainy days have been computed.

\section{Rice gundhi bug, Leptocorisaacuta (Thunberg)}

Rice gundhi bug was first appeared during $33^{\text {rd }} \mathrm{SW}$ in light trap catches. Major active period was August to December with two distinct peaks $41^{\text {st }} \mathrm{SW}$ and $45^{\text {th }} \mathrm{SW}$. Highest peak was recorded during $45^{\text {th }} \mathrm{SW}$.

In accordance with the present findings, Sharma et al., (2011) also reported through light trap collection over 15 years that maximum population of $L$. acuta was observed during third week of October. Similarly Venkatesh et al., (2009) also reported that higher activity of ear head bug, Leptocorisa sp. was observed during September to October in light trap catches, While Rai et al., (1990) reported two peaks of L. acuta in the $37^{\text {th }}$ and $40^{\text {th }}$ weeks of each year.

Correlation studies between various weather parameters and rice gundhi bug catches were found non significant.

In contrast with the present findings, Sharma et al (2004) found that rainfall had positive correlation of order 0.857 with population build up of L. acuta whereas Bhatnagar and Saxena (1999) found a positive correlation between maximum temperature and sunshine and trap catches of L. acuta, they also found significant negative correlation of minimum temperature, evening relative humidity and rainfall with light tap catches of L. acuta at Jagdalpur, India.

\section{Green leaf hopper, Nephotettixvirescens (Distant)}

Green leaf hopper was first appeared during $32^{\text {nd }} \mathrm{SW}$ in light trap. Major activity period was August to December with three distinct peaks during $34^{\text {th }} \mathrm{SW}, 38^{\text {th }} \mathrm{SW}$ and $42^{\text {nd }} \mathrm{SW}$ respectively. Highest peak was recorded during $34^{\text {th }} \mathrm{SW}$.

Confirms the present findings Sharma et. al. (2004) who also reported that maximum population of N.virescens was recorded during the $3^{\text {rd }}$ week of October. On the contrary Rai et al., (2002), Manimaran and Manickavasagam (2000) and Sabale et al., (2010) reported that peak activity of $N$. virescens in light trap was observed during first fort night of August, month of September (Kuruvai season in Tamil Nadu) and $38^{\text {th }}$ to $41^{\text {st }} \mathrm{SW}, 45^{\text {th }} \mathrm{SW}$ and $52^{\text {nd }}$ to $2^{\text {nd }} \mathrm{SW}$ at Pattambi, Kerala respectively, Kathirvelu and Manickavasgam (2007) also recorded green leafhopper (GLH) during the $33^{\text {rd }}$ and $35^{\text {th }} \mathrm{SW}$ respectively through trap catches.

Correlation between green leafhopper and maximum temperature, minimum temperature, sunshine, evening relative humidity, wind velocity, morning vapor pressure, evening vapor pressure and evaporation showed positive correlation with hopper catches, but statistically found non 
significant while rainfall, morning relative humidity and number of rainy days exhibited negative correlation and statistically found non significant.

Similarly Kathirvelu and Manickavasgam (2007) reported positive correlation $N$. virescens catches in light trap and maximum, minimum temperature and sunshine except rainy days. Joseph et al., (1994) also observed inverse relationship between the trap catches of $N$. virescens and relative humidity, while Samim et al., (2009) revealed that the bright sunshine hours had a significant positive correlation $(r=0.166)$ with green leaf hopper.

\section{Army worm, Mythimna separata (Walker)}

Army worm was first appeared during $36^{\text {th }}$ SW in light trap catches. The activity period of Mythimna separata (Walker) was observed from September to December, higher numbers during $45^{\text {th }} \mathrm{SW}$ (forming the highest peak).

In accordance with the present findings Sharma et al., (2013) reported that highest peaks of $M$. separata were observed during $3^{\text {rd }}$ week of September and November. Sharma et al., (2002) also reported that Mythimna separata (Walker) was observed highest in trap catches during September but first appearance of Mythimna separata (Walker) adults in trap catches was observed 15-20 days after initiation of the monsoon rains in the first week of June, which is in contrast with the present finding.

Correlation between various weather parameters and moth catches of army worm were found non significant.

On contrast to the present findings, Muchhala (2014) reported that maximum temperature and evaporation exhibited a significant positive effect on moths catches, while
Sharma et al., (2013) found that higher rainfall, lower mean maximum temperature and higher relative humidity were favourable for M. separata. Sharma et al., (2002) reported that rainfall, morning and evening relative humidity were positively associated with trap catches, while maximum temperature, evaporation, sunshine and wind velocity showed a negative correlation with trap catches of $M$. separata.

\section{Rice leaf folder, Cnaphalocrocis medinalis (Guene)}

Rice leaf folder was first recorded during $38^{\text {rth }}$ $\mathrm{SW}$ in light trap. The activity period of $C$. medinalis was observed from September to October. The one's only one distinct peak was recorded in $41^{\text {st }} \mathrm{SW}$.

Patel et al., (2011) also reported that rice leaf folder, $C$. medinalis reached its peak level during $43^{\text {rd }} \mathrm{SW}$, Khan and Ramamurthy (2004) revealed that the moth numbers were higher in the month of October, followed by September.

In contrast with the present findings, Harinkhere et al., (1998) who reported that first appearance of $C$. medinalis in trap catches started from $2^{\text {nd }}$ week of August and major peaks were observed during September to October in Balaghat (M.P.). Similarly Manisegaran and Letchoumanane (2001) reported that weekly catches of rice leaf folder were highest during October and November in Tamil Nadu. Sharma et. al. (2013) recorded 3 distinct peaks of rice leaf folder during the main cropping season of paddy in which highest weekly peaks were observed during the $4^{\text {rth }}$ week of September and October.

Correlation between various weather parameters and adults of rice leaf folder catches were found non significant. 
In conformity with the present findings, Muchhala (2014) also observed that all the weather parameters did not show any significant effect on moth catches, while Patel et al., (2011) reported that wind velocity ( $\mathrm{r}=-$ $0.539)$ and rainy days $(\mathrm{r}=-0.518)$ had significant negative correlation.

Sabir et al., (2006) observed that the maximum and minimum temperature had negative effect, while rainfall having positive effect on trap catches of $C$. medinalis. Kathirvelu and Manickavasgam (2007) also reported that leaf folder had significant negative correlation with maximum temperature and significant positive correlation with sunshine.

\section{Rice butterfly, Melanitis ledaismene Cramer}

Rice butterfly was first recorded during $35^{\text {th }}$ SW in light trap. The activity period of $M$. ledaismene was observed from August to November with two distinct peaks, $41^{\text {st }} \mathrm{SW}$ and $42^{\text {nd }} \mathrm{SW}$. The highest weekly peak was observed in $41^{\text {st }} \mathrm{SW}$.

Muchhala (2014) reported three distinct peaks during $38^{\text {rth }}, 42^{\text {nd }}$ and $44^{\text {rth }} \mathrm{SW}$, respectively. Major activity period was observed from August to December at Jabalpur. On contrary to the present findings, Sharma (2004) reported that major activity period of Melanitis ledaismene Cramer was observed in light trap from July to October with highest monthly catches during September at Jabalpur, M.P.

Correlation between various weather parameters and rice butterfly catches were found non significant, except maximum temperature, which exhibited a significant positive effect on butterfly catches. Similarly Muchhala (2014) was reported that maximum temperature exhibited a significant positive effect on butterfly catches.

Short horn grass hopper, Tetrixsubulata Linnaeus

Short horn grass hopper was first observed in light trap during $26^{\text {th }} \mathrm{SW}$. Major activity period was June to December with three distinct peak $32^{\text {nd }} \mathrm{SW}, 36^{\text {th }} \mathrm{SW}$ and $41^{\text {st }} \mathrm{SW}$ respectively. The highest peak was observed $41^{\text {st }} \mathrm{SW}$.

Williams et al., (1996) also observed Tetrix subulata Linnaeus in light trap catches. In contrast to the present findings Sharma (2006) observed two species of grass hopper viz. Trilophidia cristella S. and Gastrimargus transversus in light trap catches in paddy field during 2002 (kharif season) at Jabalpur, while similar to the present findings, Singh and Ramaneek (2007) reported that population fluctuations of twenty four species of orthopterans, were correlated with temperature and relative humidity,

In all six families viz. Gryllidae, Gryllotalpidae, Tettigoniidae (belonging to Suborder Ensifera) and Acrididae, Tridactylidae, and Tetrigidae (belonging to Suborder Caelifera) were collected. Gryllidae was found dominant followed by Tetrigidae as compared to other families.

The correlation coefficients between $T$. subulata and minimum temperature, sunshine, wind velocity, morning vapor pressure, evening vapor pressure and number of rainy days exhibited positive effect but statistically found non significant except maximum temperature that is significant while rainfall, morning relative humidity and evening relative humidity showed negative effect but statistically found non significant.

On contrary to the present findings Muchhala (2014) reported correlation between various weather parameters and grass hopper catches were found to non significant, except 
sunshine, which exhibited a significant positive effect on hoppers catches while wind velocity and number of rainy days showed a significant negative effect on hoppers catches.

Field cricket, Euscyrtus concinnus (de Haan)

Field cricket was first recorded during $26^{\text {th }}$ SW in light trap. The activity period of $E$. concinnus was observed from June to December with two distinct peaks during $38^{\text {th }}$ and $40^{\text {th }} \mathrm{SW}$.

The highest peak was observed in $38^{\text {th }} \mathrm{SW}$.

In conformity with the present finding Sharma et al., (2004) also reported the major activity period of field cricket between July and October with maximum monthly catches during July. While Rathore (2001) reported that major activity period of field cricket was observed during September to October. Highest monthly catches were recorded during September (320 crickets).

The correlation studies between maximum temperature and evaporation showed significant positive correlation with field cricket catches. Minimum temperature, sunshine, wind velocity, morning vapor pressure and number of rainy days also showed positive correlation, but statistically found non significant while morning relative humidity, evening relative humidity and evening vapor pressure exhibited negative correlation, and statistically found non significant.

On contrary to the present findings Meena (2015) reported correlation between minimum temperature, rainfall, evening relative humidity, wind velocity, morning vapor pressure, evening vapor pressure and number of rainy days showed significant positive correlation and field cricket catches was found significantly positive, while sunshine exhibited a significant negative effect on crickets catches. Effect of maximum temperature, morning relative humidity and evaporation was found non significant.

\section{Mole cricket, Gryllotalpa orientalis Burmeister}

Mole cricket was first recorded during $26^{\text {th }}$ SW in light trap. The activity period of Gryllotalpaorientalis Burmeister was observed throughout the season (June to December) with two distinct peaks during $37^{\text {th }}$ and $40^{\text {th }} \mathrm{SW}$, during the highest peak $37^{\text {th }} \mathrm{SW}$.

Similarly Rathore (2001) also reported that major activity period of mole cricket was observed during September to October with highest monthly catches during September (285 crickets) at Jabalpur. In contrast to the present findings, Wang et al., (2013) reported that the mole cricket (Gryllotalpa sp.) had two damage peaks (late May to early July, early September to mid and late October) at Hangzhou China. Bhowmick (1985) reported that highest monthly catches of mole crickets were recorded during November (1395 adults) at Waraseoni, Balaghat, Madhya Pradesh.

Correlation between various weather parameters and mole cricket catches were found non significant, except maximum temperature and evaporation, which exhibited a significant positive effect on crickets catches.

Similarly Muchhala (2014) reported that correlation between various weather parameters and mole cricket catches were found non significant, except maximum temperature, which exhibited a significant positive effect on crickets catches.

In contrast to the present findings Meena (2015) reported correlation between various weather parameters and mole cricket catches 
were found non significant, except minimum temperature, evening relative humidity morning vapor pressure and evening vapor pressure, which exhibited a significant positive effect on mole crickets catches.

Table.1 Seasonal incidence of insect pest species of paddy during kharif (June to December) 2015 (Weekly average)

\begin{tabular}{|c|c|c|c|c|c|c|c|c|}
\hline SW & $\begin{array}{l}\text { Leptocorisa } \\
\text { acuta } \\
\text { (Thunberg) }\end{array}$ & $\begin{array}{l}\text { Nephotetti } \\
\text { xvirescens } \\
\text { (Distant) }\end{array}$ & $\begin{array}{l}\text { Mythimnase } \\
\text { parata } \\
\text { (Walker) }\end{array}$ & $\begin{array}{l}C . \\
\text { medinalis } \\
\text { (Guene) }\end{array}$ & $\begin{array}{l}\text { Melanitisl } \\
\text { edaismene } \\
\text { Cramer }\end{array}$ & $\begin{array}{l}\text { Tetrixsub } \\
\text { ulata } \\
\text { Linnaeus }\end{array}$ & $\begin{array}{l}\text { Euscyrtusc } \\
\text { oncinnus } \\
\text { (de Haan) }\end{array}$ & $\begin{array}{l}\text { Gryllotalpa } \\
\text { orientalis } \\
\text { Burmeister }\end{array}$ \\
\hline 26 & 0.00 & 0.00 & 0.00 & 0.00 & 0.00 & 5.50 & 235.30 & 2.50 \\
\hline 27 & 0.00 & 0.00 & 0.00 & 0.00 & 0.00 & 3.50 & 78.14 & 4.57 \\
\hline 28 & 0.00 & 0.00 & 0.00 & 0.00 & 0.00 & 2.20 & 64.29 & 1.14 \\
\hline 29 & 0.00 & 0.00 & 0.00 & 0.00 & 0.00 & 2.71 & 107.14 & 4.43 \\
\hline 30 & 0.00 & 0.00 & 0.00 & 0.00 & 0.00 & 1.20 & 78.14 & 1.57 \\
\hline 31 & 0.00 & 0.00 & 0.00 & 0.00 & 0.00 & 0.57 & 0.71 & 0.29 \\
\hline 32 & 0.00 & 1.43 & 0.00 & 0.00 & 0.00 & 3.00 & 12.14 & 0.43 \\
\hline 33 & 1.14 & 1.71 & 0.00 & 0.00 & 0.00 & 2.00 & 2.71 & 0.43 \\
\hline 34 & 5.43 & 131.43 & 0.00 & 0.00 & 0.00 & 1.86 & 14.57 & 0.29 \\
\hline 35 & 4.86 & 49.29 & 0.00 & 0.00 & 0.29 & 3.29 & 13.00 & 3.86 \\
\hline 36 & 6.43 & 37.86 & 5.71 & 0.00 & 6.00 & 4.43 & 80.57 & 1.43 \\
\hline 37 & 8.43 & 0.00 & 4.21 & 0.00 & 3.00 & 1.14 & 45.29 & 8.14 \\
\hline 38 & 5.00 & 124.29 & 2.10 & 1.50 & 2.29 & 1.86 & 281.43 & 4.86 \\
\hline 39 & 8.57 & 88.86 & 3.80 & 3.00 & 2.43 & 0.43 & 69.29 & 2.57 \\
\hline 40 & 11.00 & 34.71 & 4.45 & 2.00 & 9.57 & 1.43 & 244.29 & 5.86 \\
\hline 41 & 17.00 & 90.00 & 9.00 & 5.70 & 34.14 & 6.14 & 170.00 & 3.00 \\
\hline 42 & 10.00 & 113.14 & 8.86 & 0.00 & 12.29 & 4.71 & 217.57 & 3.29 \\
\hline 43 & 13.43 & 67.86 & 8.86 & 0.00 & 2.43 & 3.00 & 25.71 & 2.14 \\
\hline 44 & 18.14 & 83.14 & 12.14 & 0.00 & 0.43 & 3.71 & 21.14 & 4.14 \\
\hline 45 & 32.14 & 44.29 & 18.14 & 0.00 & 7.71 & 2.14 & 21.14 & 3.14 \\
\hline 46 & 11.71 & 19.29 & 5.00 & 0.00 & 0.14 & 1.50 & 7.57 & 1.43 \\
\hline 47 & 2.43 & 3.71 & 1.43 & 0.00 & 0.00 & 0.14 & 19.00 & 0.71 \\
\hline 48 & 2.57 & 0.14 & 0.29 & 0.00 & 0.00 & 0.71 & 5.00 & 0.86 \\
\hline 49 & 0.00 & 0.00 & 3.14 & 0.00 & 0.00 & 0.00 & 0.00 & 0.00 \\
\hline 50 & 0.00 & 0.00 & 0.86 & 0.00 & 0.00 & 0.00 & 0.00 & 0.00 \\
\hline 51 & 0.00 & 0.00 & 5.14 & 0.00 & 0.00 & 0.00 & 0.00 & 0.00 \\
\hline 52 & 0.00 & 0.00 & 1.71 & 0.00 & 0.00 & 0.00 & 0.00 & 0.00 \\
\hline
\end{tabular}


Table.2 Correlation coefficient of weather factors on light trap catches of Leptocorisaacuta (Thunberg) and Nephotettix virescens (Distant)

\begin{tabular}{|c|c|c|c|c|}
\hline \multirow[t]{2}{*}{ Weather Parameter } & \multicolumn{2}{|c|}{$\begin{array}{l}\text { Leptocorisa acuta } \\
\text { (Thunberg) }\end{array}$} & \multicolumn{2}{|c|}{$\begin{array}{l}\text { Nephotettix virescens } \\
\text { (Distant) }\end{array}$} \\
\hline & $\mathbf{r}$ & Byx & $\mathbf{R}$ & Byx \\
\hline Maximumtemperature $\left({ }^{\circ} \mathrm{C}\right)$ & $0.14 \mathrm{NS}$ & - & $0.28 \mathrm{NS}$ & - \\
\hline Minimumtemperature $\left({ }^{\circ} \mathrm{C}\right)$ & $-0.45 \mathrm{NS}$ & - & $0.05 \mathrm{NS}$ & - \\
\hline Sunshine (hrs) & $0.18 \mathrm{NS}$ & - & $0.28 \mathrm{NS}$ & - \\
\hline Rainfall (mm) & $-0.36 \mathrm{NS}$ & - & $-0.01 \mathrm{NS}$ & - \\
\hline Morning relative humidity (\%) & $-0.15 \mathrm{NS}$ & - & $-0.24 \mathrm{NS}$ & - \\
\hline Evening relative humidity (\%) & $-0.36 \mathrm{NS}$ & - & $0.03 \mathrm{NS}$ & - \\
\hline Wind Velocity $(\mathbf{k m} / \mathbf{h r})$ & $-0.43 \mathrm{NS}$ & - & $0.37 \mathrm{NS}$ & - \\
\hline Morning vapor pressure (mm) & $-0.33 \mathrm{NS}$ & - & $0.12 \mathrm{NS}$ & - \\
\hline Evening vapor pressure (mm) & $-0.37 \mathrm{NS}$ & - & $0.05 \mathrm{NS}$ & - \\
\hline Evaporation (mm) & $-0.22 \mathrm{NS}$ & - & $0.36 \mathrm{NS}$ & - \\
\hline Number of rainy days & $-0.41 \mathrm{NS}$ & - & $-0.05 \mathrm{NS}$ & - \\
\hline
\end{tabular}

Table.3 Correlation coefficient of weather factors on light trap catches of Mythimna separata (Walker) Cnaphalocrocis medinalis (Guene) and Melanitis ledaismene Cramer

\begin{tabular}{|c|c|c|c|c|c|c|}
\hline \multirow[t]{2}{*}{ Weather Parameter } & \multicolumn{2}{|l|}{$\begin{array}{l}\text { Mythimna } \\
\text { (Walker) }\end{array}$} & \multicolumn{2}{|c|}{$\begin{array}{l}\text { Cnaphalocrocis } \\
\text { medinalis (Guene) }\end{array}$} & \multicolumn{2}{|c|}{$\begin{array}{l}\text { Melanitis ledaismene } \\
\text { Cramer }\end{array}$} \\
\hline & $\mathbf{r}$ & byx & $\mathbf{R}$ & Byx & $\mathbf{R}$ & byx \\
\hline $\begin{array}{l}\text { Maximum } \\
\text { temperature }\left({ }^{\circ} \mathrm{C}\right)\end{array}$ & $0.31 \mathrm{NS}$ & - & $0.93 \mathrm{NS}$ & - & $0.65 *$ & 3.29 \\
\hline $\begin{array}{l}\text { Minimum temperature } \\
\left({ }^{\circ} \mathrm{C}\right)\end{array}$ & $0.21 \mathrm{NS}$ & - & $-0.78 \mathrm{NS}$ & - & $-0.17 N S$ & - \\
\hline Sunshine (hrs) & $-0.23 \mathrm{NS}$ & - & $0.60 \mathrm{NS}$ & - & $0.52 \mathrm{NS}$ & - \\
\hline Rainfall (mm) & $0.01 \mathrm{NS}$ & - & $-0.55 \mathrm{NS}$ & - & $-0.35 \mathrm{NS}$ & - \\
\hline $\begin{array}{ll}\text { Morning } & \text { relative } \\
\text { humidity }(\%) & \end{array}$ & $0.04 \mathrm{NS}$ & - & $-0.33 \mathrm{NS}$ & - & $-0.29 \mathrm{NS}$ & - \\
\hline $\begin{array}{ll}\text { Evening } & \text { relative } \\
\text { humidity }(\%) & \end{array}$ & $0.20 \mathrm{NS}$ & - & $-0.68 \mathrm{NS}$ & - & $-0.57 \mathrm{NS}$ & - \\
\hline Wind Velocity (km/hr) & $-0.07 \mathrm{NS}$ & - & $-0.55 \mathrm{NS}$ & - & $-0.41 \mathrm{NS}$ & - \\
\hline $\begin{array}{ll}\text { Morning } & \text { vapor } \\
\text { pressure }(\mathbf{m m}) & \end{array}$ & $0.21 \mathrm{NS}$ & - & $-0.90 \mathrm{NS}$ & - & $-0.32 \mathrm{NS}$ & - \\
\hline $\begin{array}{ll}\text { Evening } & \text { vapor } \\
\text { pressure }(\mathrm{mm}) & \end{array}$ & $0.20 \mathrm{NS}$ & - & $-0.75 \mathrm{NS}$ & - & $-0.44 N S$ & - \\
\hline Evaporation (mm) & $0.01 \mathrm{NS}$ & - & $-0.46 \mathrm{NS}$ & - & $0.26 \mathrm{NS}$ & - \\
\hline Number of rainy days & $-0.09 \mathrm{NS}$ & - & $-0.55 \mathrm{NS}$ & - & $-0.35 \mathrm{NS}$ & - \\
\hline \multicolumn{7}{|c|}{$*=$ Significant at 0.05 level $\quad$ NS $=$ Non Significant } \\
\hline
\end{tabular}


Table.4 Correlation coefficient of weather factors on light trap catches of Tetrix subulata Linnaeus Euscyrtus concinnus (de Haan) and Gryllotalpa orientalis Burmeister

\begin{tabular}{|c|c|c|c|c|c|c|}
\hline \multirow[t]{2}{*}{ Weather Parameter } & \multicolumn{2}{|c|}{$\begin{array}{ll}\text { Tetrix } & \text { subulata } \\
\text { Linnaeus } & \end{array}$} & \multicolumn{2}{|c|}{$\begin{array}{l}\text { Euscyrtus } \\
\text { concinnus } \\
\text { Haan) }\end{array}$} & \multicolumn{2}{|c|}{$\begin{array}{l}\text { Gryllotalpa } \\
\text { orientalis } \\
\text { Burmeister }\end{array}$} \\
\hline & $\mathbf{r}$ & byx & $\mathbf{R}$ & Byx & $\mathbf{R}$ & byx \\
\hline Maximum temperature $\left({ }^{\circ} \mathrm{C}\right)$ & $0.47 *$ & 0.44 & $0.55 * *$ & 28.67 & $0.42 *$ & 0.50 \\
\hline Minimum temperature $\left({ }^{\circ} \mathrm{C}\right)$ & $0.04 \mathrm{NS}$ & - & $0.11 \mathrm{NS}$ & - & $0.01 \mathrm{NS}$ & - \\
\hline Sunshine (hrs) & $0.01 \mathrm{NS}$ & - & $0.27 \mathrm{NS}$ & - & $0.21 \mathrm{NS}$ & - \\
\hline Rainfall (mm) & $-0.04 \mathrm{NS}$ & - & $-0.05 N S$ & - & $-0.20 \mathrm{NS}$ & - \\
\hline Morning relative humidity (\%) & $-0.21 \mathrm{NS}$ & - & $-0.22 \mathrm{NS}$ & - & $-0.02 \mathrm{NS}$ & - \\
\hline Evening relative humidity (\%) & $-0.01 N S$ & - & $-0.18 \mathrm{NS}$ & - & $-0.13 N S$ & - \\
\hline Wind Velocity $(\mathrm{km} / \mathrm{hr})$ & $0.06 \mathrm{NS}$ & - & $0.03 \mathrm{NS}$ & - & $-0.14 N S$ & - \\
\hline Morning vapor pressure (mm) & $0.08 \mathrm{NS}$ & - & $0.14 \mathrm{NS}$ & - & $0.12 \mathrm{NS}$ & - \\
\hline Evening vapor pressure (mm) & $0.09 \mathrm{NS}$ & - & $-0.01 \mathrm{NS}$ & - & $0.04 \mathrm{NS}$ & - \\
\hline Evaporation (mm) & $0.22 \mathrm{NS}$ & - & $0.51 *$ & 66.01 & $0.43 *$ & 1.29 \\
\hline Number of rainy days & $0.19 \mathrm{NS}$ & - & $0.09 \mathrm{NS}$ & - & $0.01 \mathrm{NS}$ & - \\
\hline \multicolumn{7}{|c|}{ NS = Non Significant } \\
\hline
\end{tabular}

It is concluded based on the result that showed all 8 species were identified as pests of paddy having regular occurrence in light trap catches i.e. Rice gundhi bug, Leptocorisa acuta (Thunberg), Green leaf hopper, Nephotettix virescens (Distant), Army worm, Mythimna separata (Walker), Rice leaf folder, Cnaphalocrocis medinalis (Guene), Rice butterfly, Melanitis ledaismene Cramer, Short horn grass hopper, Tetrix subulata Linnaeus, Field cricket, Euscyrtus concinnus (de Haan) and Mole cricket, Gryllotalpa orientalis Burmeister. Correlation studies revealed that between various weather parameters and Rice gundhi bug, Leptocorisa acuta (Thunberg), Green leaf hopper, Nephotettix virescens (Distant), Army worm, Mythimna separata (Walker), Rice leaf folder, Cnaphalocrocis medinalis (Guene) catches were found non significant and Rice butterfly, Melanitisledaismene Cramer and Short horn grass hopper, Tetrix subulata Linnaeus showed that significant positive correlation with maximum temperature while Field cricket, Euscyrtus concinnus (de Haan), Mole cricket, Gryllotalpa orientalis Burmeister catches were found significant positive correlation with maximum temperature and evaporation.

\section{Acknowledgement}

This research was supported by Department of Entomology, JNKVV, Jabalpur. We are thankful to our colleagues Mr. Anil Kurmi who provided expertise that greatly assisted the research, although they may not agree with all of the interpretations provided in this paper.

We are also grateful to Dr. A.K. Sharma for assistance with research and analysis who moderated this paper and in that line improved the manuscript significantly. We have to express out appreciation to the Dr. A. $\mathrm{K}$. Bhowmick for sharing their pearls of 
wisdom with us during the course of this research.

\section{References}

Anonymous. 2015. Rice in India hand book of statistics, Director of Rice Development, Government of India, Hyderabad (A.P.).

Anonymous. 2016. Agriculture Statistics at a glance, Department of Agriculture and co-operation, Ministry of Agriculture, Government of India, New Delhi.

Bhatnagar Anuj and Saxena RR. 1999. Environmental correlates of population build up of rice insect pests through light trap catches. Oryza, 36(3): 241-245.

Bhowmick AK. 1985. Role of light trap in surveillance and management of insect pests of forest trees of major economic importance. Ph.D. Thesis, RDVV, Jabalpur. 85p.

Dhaliwal GS and Arora R. 2010. Integrated Pest Management. Kalyani Publishers, New Delhi, India, 369 p.

Dhamdhere $\mathrm{SV}$. 1990. PhansalonKePramukhHanikarkKeet. Haryana Sahitya Academy, Chandigarh, 374p.

Harinkhere JP, Kandalkar VS and Bhowmick AK. 1998. Seasonal abundance and association of light trap catches with field incidence of rice leaf folder (CnaphalocrocismedinalisGuenee). Oryza, 35(1): 91-92.

Joseph D, Amma PRKK, Nair KPV, Devi DA, Thomas B and Joseph CA. 1994. Seasonal fluctuations in the population of four major insect pests of rice in Kuttanad. Bulletin of Entomology (New Delhi), 35(1-2): 107-112.

Kathirvelu C and Manickavasgam S. 2007. Correlation of light trap catches of important parasitoids, predators and pest complex of rice with meteorological parameters. Hexapoda,
14(1): 9-14.

Khan ZH and Ramamurthy VV. 2004. Influence of weather factors on the activity of rice leaf folder, Cnaphalocrocis medinalis (Guene). Annual of Plant Protection Sciences, 12(2): 267-270.

Manimaran D and Manickavasagam S. 2000. Light trap catches of hoppers and mirid in rice. Insect Environment, 5(4): 156-157.

Manisegaran S and Letchoumanane S. 2001. Influence of weather factors on the population of rice leaf folder in the coastal region of Karaikal. Madras Agricultural Journal, 88(7/9): 502503.

Meena S. 2015. Studies on Lepidopteron fauna and major insect pest species of paddy ecosystem collected in light trap at Jabalpur region'. M.Sc Thesis, JNKVV, Jabalpur, 1-110p.

Muchhala Y. 2014. Study on insect pest fauna of paddy ecosystem collected in light trap in Jabalpur region. M.Sc Thesis, JNKVV, Jabalpur, 1-109p.

Patel HN, Kadu RV and Landge SA. 2011. Study on seasonal incidence of rice leaf folders (Cnaphalocrocis medinalis Guen. and Pelopidas mathias $\mathrm{Fb}$.) of paddy and its correlation with weather parameters. International Journal of Plant Protection, 4(1): 175-180.

Pathak MD and Dhaliwal GS. 1981. Trend and strategies for rice insect problems in tropical Asia. IRRI Research Paper Series No, 64.

Rai AB, Singh J and Rai L. 1990. Rice bug (Leptocorisa varicornis Fab.) appearance on light trap in eastern Uttar Pradesh, India. Oryza, 27(1): 6672.

Rai AK and Khan MA. 2002. Light trap catch of rice insect pest, Nephotettix virescens (Distant) and its relation 
with climatic factors. Annual of Plant Protection Sciences, 10(1): 17-22.

Ramamurthy VV, Akhtar MS, Patankar NV, Menon Pratibha, Kumar Rajesh, Singh SK, Shama Shaloo Ayri and Mittal Parveen Vishal. 2010. Efficiency of different light sources in light traps in monitoring insect diversity, Munis Entomology and Zoology, 5(1): 109114.

Rathore MS. 2001. Studies on the major insect pests of vegetables collected in light trap in vegetable area at Jabalpur. M. Sc. Thesis, JNKVV, Jabalpur, 29$35 \mathrm{p}$.

S.M. Dadmal and SuvarnaKhadakkar. (2014). Insect faunal diversity collected through light trap at Akola vicinity of Maharashtra with reference to Scarabaeidae of Coleoptera. Journal of Entomology and Zoology Studies, 2 (3): 44-48

Sabale JP, Chandana Das and Samui RP. 2010. Influence of weather factors on light trap catches of green leaf hopper at Pattambi, Kerala. Journal of Agrometeorology, 12(1): 108-110.

Sabir AM, Sohail Ahmed, Mansoor-UlHassan Sahi and Abdul Qadir. 2006. Pest weather interaction of major insect pest in rice ecosystem. SAARC Journal of Agriculture, 4: 203-212.

Shamim M, Shekh AM, Patel VJ, Dodia JF, Korat DM and Mehta AM. 2009. Effect of weather parameters on population dynamics of green leaf hopper and white backed plant hopper in paddy grown in middle Gujarat region. Journal of Agrometeorology, 11(2): 172-174.

Sharma AK and Vaishampayan SM. 2009. Evaluation of light trap as eco friendly control tool in the management of insect pest species of paddy ecosystem. JNKVV Research Journal, $187 \mathrm{p}$.
Sharma AK, Barche S and Mishra PK. 2004. Scope of light trap as IPM tool for sustainable cultivation of rice. Modern Biotechnology and its Application, Pp. 303-312.

Sharma AK, Barche S and Mishra PK. 2010. Pest and predatory insect species inhabiting paddy ecosystem in Jabalpur, Madhya Pradesh collected with the help of light traps. Pest Management and Economic Zoology, 18(1/2): 125-133.

Sharma AK, Barche S and Mishra PK. 2013. Seasonal activity of Sogatella furcifera H., Cnaphalocropcis medinalis G. and Mythimna separataW. in relation to weather parameters in Central India. Technofame, 19-29 p.

Sharma AK, Vaishampayan $\mathrm{S}$ and Vaishampayan SM. 2006. Distribution of insect pests fauna of rice ecosystem collected through light trap at Jabalpur. JNKVV Research Journal, 40(1\&2): 50-60.

Sharma HC, Sullivan DJ and Bhatnagar VS. 2002. Population dynamics and natural mortality factors of the Oriental armyworm, Mythimna separata (Lepidoptera: Noctuidae), in South-Central India. Crop Protection 21(9): 721-732.

Sharma MK, Asrat Atsedewoin and Fanta S. 2011. Forewarning models of the insects of paddy crop. International Journal of Biodiversity and Conservation, 3(8): 367-375.

Sharma MK, Pandey V, Singh RS and Singh RA. 2004. A study on light trap catches of some rice pests in relation to meteorological factors. Sinet Ethiopian Journal of Science, 27(2): 165-170.

Shimoda M and Honda K.2013. Insect reactions to light and its applications to pest management. Applied 
Entomology and Zoology, 48(4): 413421.

Singh Devinder and Ramaneek HB. 2007. Population dynamics of Orthoptera (Insecta) collected from light trap. Journal of Entomological Research, 31(1): 63-71.

Snedecor, GW., and Cochran, WG. 1967. Statistical Methods. Oxford and IBH Publishing Company. New Delhi. 1$292 \mathrm{p}$.

VenkateshHosamani, Pradeep S, Sridhara S and Naik MI. 2009. Incidence of rice earhead bug, Leptocorisa oratorius (F.) (Hemiptera: Alydidae) in Bhadra command area and effect of its feeding on grain damage. Environment and Ecology, 27(2): 708712.
Verma R and Vaishampayan SM. 1983. Seasonal activity of major insect pests on light trap equipped with mercury vapour lamp at Jabalpur. Insect ecology and resource management, 173-180p.

Wang DaoZe, Hong WenYing, Wu YanJun, Wang AiJuan and Wei JiQian. 2012. Study on the occurrence regularity and prediction model of underground pest adults in Hangzhou district [Chinese]. Acta Agriculturae Zhejiangensis; 24(6): 1050-1057.

Williams RN, Ellis MS and Fickle DS. 1996. Insects in the Killbuck Marsh Wildlife Area. Ohio Journal of Science, 96(3): 34-40.

\section{How to cite this article:}

Yogendra Kumar Mishra, A.K. Sharma, A.K. Bhowmick, A.K. Saxena and Anil Kurmi. 2019. Seasonal Incidence of Insect Pest Species of Paddy Collected through Light Trap. Int.J.Curr.Microbiol.App.Sci. 8(04): 381-393. doi: https://doi.org/10.20546/ijcmas.2019.804.042 